\title{
Methods for the Preparation and Analysis of Solids and Suspended Solids for Total Mercury
}

Chapter 8 of

Book 5, Laboratory Analysis

Section A, Water Analysis

Techniques and Methods 5 A-8 


\section{Methods for the Preparation and Analysis of Solids and Suspended Solids for Total Mercury}

By Shane D. Olund, John F. DeWild, Mark L. Olson, and Michael T. Tate

Chapter 8 of

Book 5, Laboratory Analysis

Section A, Water Analysis

Techniques and Methods $5 \mathrm{~A}-8$ 


\section{U.S. Department of the Interior}

Gale A. Norton, Secretary

\section{U.S. Geological Survey}

Charles G. Groat, Director

U.S. Geological Survey, Reston, Virginia: 2004

For more information about the USGS and its products:

Telephone: 1-888-ASK-USGS

World Wide Web: http://www.usgs.gov/

Any use of trade, product, or firm names in this publication is for descriptive purposes only and does not imply endorsement by the U.S. Government. 


\section{Contents}

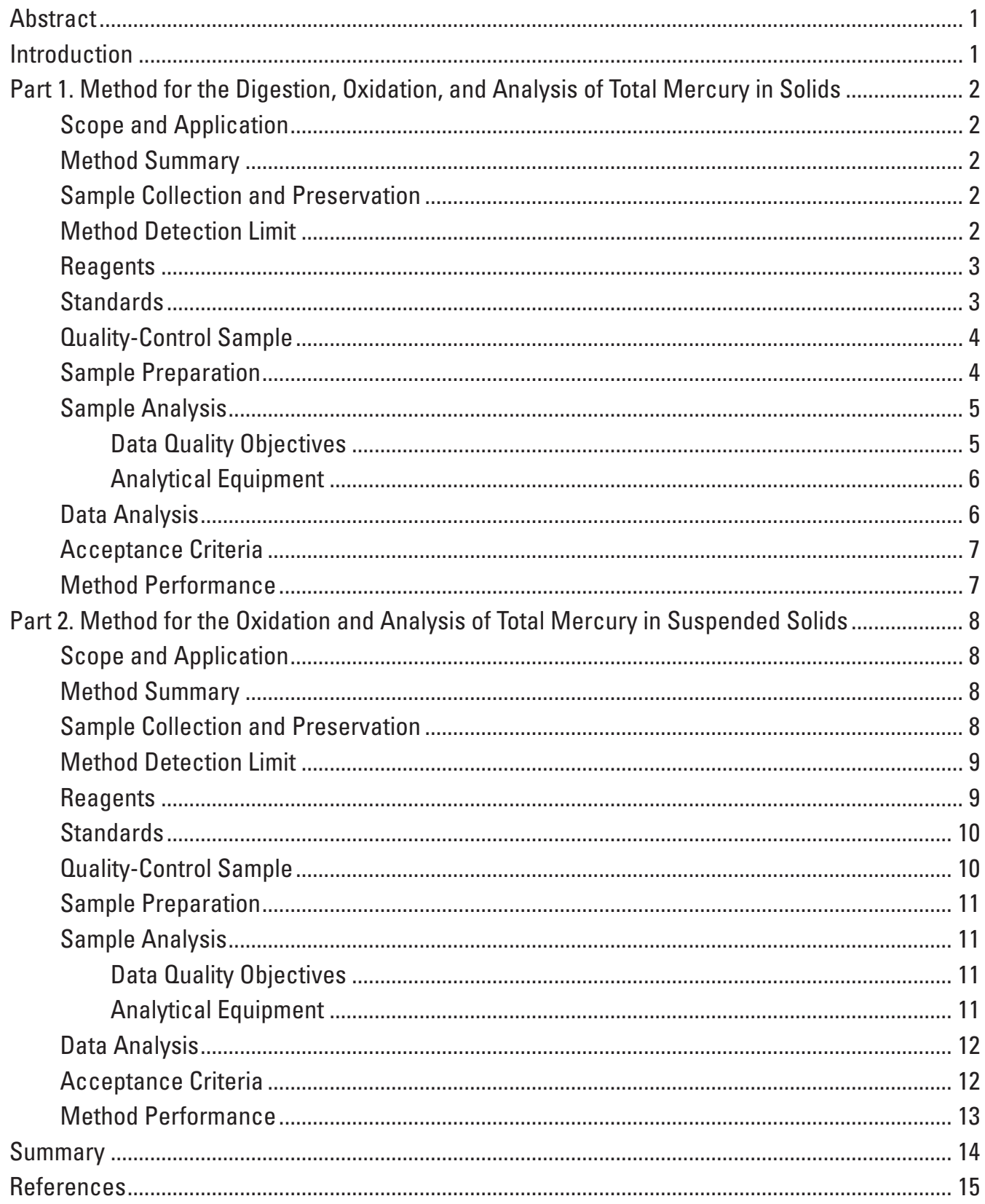




\section{Tables}

1. Results from multiple analyses of solids for method detection limit (MDL) assay.

2. Total mercury concentrations for multiple analyses of clay substrate and organic substrate solids samples

3. Percent recovery data for the clay substrate, organic substrate, and sand substrate solids samples. Each sample was spiked with 1 nanogram of mercury.......... 8

4. Results from multiple analyses of particulate MESS-2 CRM for detection limit assay

5. Results for the analysis of MESS-2 CRM solution .............................................. 13

6. Results for the analysis of IAEA-405 CRM solution ........................................................ 14 


\section{Conversion Factors}

\begin{tabular}{|c|c|c|}
\hline Multiply & By & To obtain \\
\hline \multicolumn{3}{|c|}{ Length } \\
\hline centimeter $(\mathrm{cm})$ & $3.94 \times 10^{-1}$ & inch (in) \\
\hline millimeter (mm) & $3.94 \times 10^{-2}$ & inch (in) \\
\hline micrometer $(\mu \mathrm{m})$ & $3.94 \times 10^{-5}$ & inch (in) \\
\hline \multicolumn{3}{|c|}{ Mass } \\
\hline $\operatorname{gram}(\mathrm{g})$ & $3.53 \times 10^{-2}$ & ounce, avoirdupois (oz) \\
\hline milligram (ng) & $3.53 \times 10^{-5}$ & ounce, avoirdupois (oz) \\
\hline microgram $(\mu \mathrm{g})$ & $3.53 \times 10^{-8}$ & ounce, avoirdupois (oz) \\
\hline nanogram (mg) & $3.53 \times 10^{-11}$ & ounce, avoirdupois (oz) \\
\hline \multicolumn{3}{|c|}{ Volume } \\
\hline liter $(\mathrm{L})$ & $2.64 \times 10^{-1}$ & gallon (gal) \\
\hline liter $(\mathrm{L})$ & $3.38 \times 10^{-1}$ & ounce, fluid (oz) \\
\hline milliliter (mL) & $2.64 \times 10^{-4}$ & gallon (gal) \\
\hline microliter $(\mu \mathrm{L})$ & $2.64 \times 10^{-7}$ & gallon (gal) \\
\hline \multicolumn{3}{|c|}{ Flow } \\
\hline milliliters per minute $(\mathrm{mL} / \mathrm{min})$ & $6.10 \times 10^{-2}$ & cubic inch per minute $\left(\mathrm{in}^{3} / \mathrm{min}\right)$ \\
\hline \multicolumn{3}{|c|}{ Pressure } \\
\hline pounds per square inch (psi) & 6.89 & kilopascal $(\mathrm{kPa})$ \\
\hline \multicolumn{3}{|c|}{ Resistivity } \\
\hline megohm centimeter $(\mathrm{M} \Omega-\mathrm{cm})$ & $3.94 \times 10^{-1}$ & megohm inch (M $\Omega$-in) \\
\hline
\end{tabular}

Temperature in degrees Celsius $\left({ }^{\circ} \mathrm{C}\right)$ may be converted to degrees Fahrenheit $\left({ }^{\circ} \mathrm{F}\right)$ as follows:

$$
{ }^{\circ} \mathrm{F}=\left(1.8 \times^{\circ} \mathrm{C}\right)+32
$$

Concentrations for suspended solids samples are in nanograms per liter (ng/L).

Concentrations for solids samples are in nanograms per grams $(\mathrm{ng} / \mathrm{g})$. 


\section{Abbreviated Water-Quality Units}

$\begin{array}{ll}\mathrm{g} & \text { gram } \\ \mathrm{mg} & \text { milligram }\left(10^{-3} \text { grams }\right) \\ \mu \mathrm{g} & \text { micrograms }\left(10^{-6} \mathrm{grams}\right) \\ \mathrm{ng} & \text { nanograms }\left(10^{-9} \mathrm{grams}\right) \\ \mathrm{L} & \text { liters } \\ \mathrm{mL} & \text { milliliters }\left(10^{-3} \text { liters }\right) \\ \mu \mathrm{L} & \text { microliters }\left(10^{-6} \text { liters }\right) \\ \mathrm{mg} / \mathrm{L} & \text { milligrams per liter (parts per million) } \\ \mu \mathrm{g} / \mathrm{L} & \text { micrograms per liter (parts per billion) } \\ \mathrm{ng} / \mathrm{L} & \text { nanograms per liter (parts per trillion) } \\ \mathrm{ng} / \mathrm{g} & \text { nanograms per gram (parts per billion) } \\ \mathrm{cm} & \text { centimeters (10-2 meters) } \\ \mathrm{mm} & \text { millimeters }\left(10^{-3} \text { meters }\right) \\ \mu \mathrm{m} & \text { micron }\left(10^{-6} \text { meters }\right) \\ \mathrm{mL} / \mathrm{min} & \text { milliliters per minute } \\ \mathrm{M} \Omega-\mathrm{cm} & \text { megohm centimeter } \\ \mathrm{Mmol} & \text { mega moles (10 } \mathrm{moles})\end{array}$

\section{Abbreviations and Acronyms}

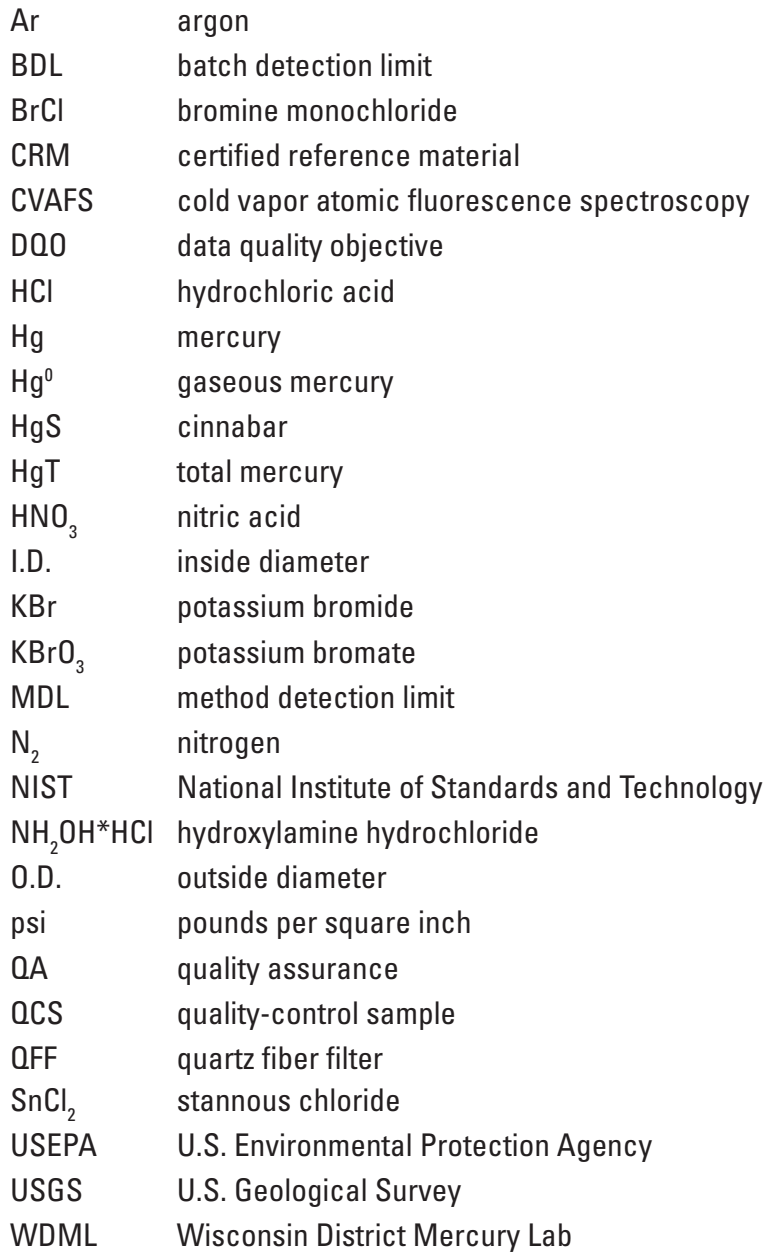




\section{Methods for the Preparation and Analysis of Solids and Suspended Solids for Total Mercury}

Olund, S.D., DeWild, J.F., Olson, M.L., and Tate, M.T.

\section{Abstract}

The methods documented in this report are utilized by the Wisconsin District Mercury Lab for analysis of total mercury in solids (soils and sediments) and suspended solids (isolated on filters). Separate procedures are required for the different sample types. For solids, samples are prepared by room-temperature acid digestion and oxidation with aqua regia. The samples are brought up to volume with a 5 percent bromine monochloride solution to ensure complete oxidation and heated at $50^{\circ} \mathrm{C}$ in an oven overnight. Samples are then analyzed with an automated flow injection system incorporating a cold vapor atomic fluorescence spectrometer. A method detection limit of $0.3 \mathrm{ng}$ of mercury per digestion bomb was established using multiple analyses of an environmental sample. Based on the range of masses processed, the minimum sample reporting limit varies from $0.6 \mathrm{ng} / \mathrm{g}$ to $6 \mathrm{ng} / \mathrm{g}$. Suspended solids samples are oxidized with a 5 percent bromine monochloride solution and held at $50^{\circ} \mathrm{C}$ in an oven for 5 days. The samples are then analyzed with an automated flow injection system incorporating a cold vapor atomic fluorescence spectrometer. Using a certified reference material as a surrogate for an environmental sample, a method detection limit of $0.059 \mathrm{ng}$ of mercury per filter was established. The minimum sample reporting limit varies from $0.059 \mathrm{ng} / \mathrm{L}$ to $1.18 \mathrm{ng} / \mathrm{L}$, depending on the volume of water filtered.

\section{Introduction}

Since the mid-1980's, scientists have redefined our understanding of the sources, cycling processes and pathways, and levels of mercury $(\mathrm{Hg})$ in various environmental media. Much of this improved understanding has been facilitated through the advancement of sampling and analytical procedures that pointed to low-level atmospheric deposition as the key $\mathrm{Hg}$ source reaching all aquatic ecosystems across the globe. In addition, even though most soils, sediments, and suspended particulates in surface waters have been relatively enriched with $\mathrm{Hg}$ over time, concentrations are still quite low and remain a significant analytical challenge to quantify accurately. The dominant repository for the vast majority of $\mathrm{Hg}$ released to the environment over the past 100 years has been surficial soils and sediments (soils and sediments: $947 \mathrm{Mmol}$; atmosphere: $17 \mathrm{Mmol}$; oceans: $36 \mathrm{Mmol}$ )(Mason and others, 1994). Thus, our ability to quantify and monitor these large pools of $\mathrm{Hg}$ is critical for assessing and continuing to improve our understanding of the global $\mathrm{Hg}$ problem. The precise chemical composition of $\mathrm{Hg}$ in soils, sediments, and suspended particulates remains difficult to quantify analytically, although in most instances it is inorganic, divalent $\mathrm{Hg}$ that is most likely sorbed to fine-grained, organic substrates (Wiener and others, 2003). Lacking species-specific methods, most researchers report total mercury (HgT) and methylmercury concentrations for solidphase environmental samples (DeWild and others, 2004). At sites distant from point sources, most soil and sediment $\mathrm{Hg}$ is derived from atmospheric deposition, and $\mathrm{HgT}$ levels range from about ten to several hundred nanograms per gram (ng/g, dry weight) (Nater and Grigal, 1992; Krabbenhoft and others, 1999). Near point sources, especially cinnabar ( $\mathrm{HgS})$ deposits or abandoned placer mines, $\mathrm{Hg}$ concentrations can be considerably higher, generally in the part per million range (Krabbenhoft and others, 1999; Biester et al. 2000; and Gustin et al. 2000). With such a wide range of concentrations observable in soils and sediments, several factors must be considered when attempting to quantify $\mathrm{HgT}$ in soils, sediment, and suspended particulates, including: (1) sample contamination due to improper sample handling or Hg-contaminated sampling devices; (2) natural heterogeneity of native materials; and, (3) matrix interferences and incomplete oxidation of samples.

This document describes the methods used by the U.S. Geological Survey (USGS) Wisconsin District 
Mercury Laboratory (WDML) in Middleton, Wisconsin, to analyze solids and suspended solids samples for $\mathrm{HgT}$ concentration and to document a method detection limit (MDL) for these sample media using the described techniques. Because the WDML employs different procedures for the preparation of solids (soils and sediments) and for suspended solids that are collected (isolated) on filters, the procedures, MDL's, and method performance are presented separately in this report. In addition, although this document will not address the need to practice "tracemetal-clean" methods during sample collection (Olson and DeWild, 1999), the utmost care should be taken to ensure reliable results when acquiring environmental samples for trace $\mathrm{Hg}$ levels.

The WDML gratefully acknowledges support for this study from the USGS Toxic Substances Hydrology Program.

\section{Part 1. Method for the Digestion, Oxidation, and Analysis of Total Mercury in Solids}

\section{Scope and Application}

This method is suitable for the determination of $\mathrm{HgT}$ in solids collected from terrestrial and aquatic environments. Samples can consist of soils or bed sediments and can be processed wet or freeze-dried. The minimum mass of $\mathrm{Hg}$ that is detectable is $0.3 \mathrm{ng}$ per digestion bomb. The upper range can be extended to meet most samples by controlling the amount of material processed and through dilutions of the digestate. All samples are reported in ng/g dry weight.

\section{Method Summary}

An aliquot of solid material homogenized with a Teflon policeman is digested and oxidized in a Teflon digestion bomb with aqua regia at room temperature overnight to convert all $\mathrm{Hg}$ to $\mathrm{Hg}^{2+}$. The digested sample is then diluted to volume with 5 percent bromine monochloride $(\mathrm{BrCl})$. After dilution, the sample is pre-reduced with hydroxylamine hydrochloride $\left(\mathrm{NH}_{2} \mathrm{OH} * \mathrm{HCl}\right)$ to remove any free halogens, then reduced with stannous chloride $\left(\mathrm{SnCl}_{2}\right)$ to convert $\mathrm{Hg}^{2+}$ to gaseous mercury $\left(\mathrm{Hg}^{0}\right)$. The $\mathrm{Hg}^{0}$ is purged, captured on a gold trap, thermally desorbed, and then detected using a cold vapor atomic fluorescence spectrometer (CVAFS). This method can be used to determine $\mathrm{HgT}$ concentrations in solid samples with a method detection limit of $0.3 \mathrm{ng}$ in a digestion bomb.

\section{Sample Collection and Preservation}

HgT analysis is extremely sensitive to contamination; therefore, care must be taken to avoid contamination during sample collection and analysis. Sample collection should be conducted using clean hands/dirty hands protocol (Olson and DeWild, 1999). Solids samples are collected and placed into precleaned vials. Collection and analysis equipment is cleaned according to the procedures outlined in DeWild and others (2002). Vials can consist of Teflon, cleaned according to DeWild and others (2002), baked glass vials (prepared by heating to $550^{\circ} \mathrm{C}$ for 4 hours), or acid-rinsed polycarbonate vials. Samples are frozen as soon as possible after collection, shipped to the lab on dry ice by overnight mail, and held at a temperature of $-15^{\circ} \mathrm{C}$ or less until processing. The WDML has not performed a holding time study; however, a frozen certified reference material (CRM) certified for $\mathrm{Hg}$ is available through the National Institute of Standards and Technology (NIST) and is stable for a duration of 9 years.

\section{Method Detection Limit}

Although samples are reported in ng/g dry weight, the MDL represented as a mass is the most effective way for the WDML to evaluate detection. It is not possible to consistently weigh out $100 \mathrm{mg}$ of solids for every sample, which is the target sample size the WDML uses. Because varying amounts of solids are processed, using an MDL based on mass per aliquot allows a direct comparison of the amount of mercury in the sample digestate to the consistent value of $0.3 \mathrm{ng}$. Although the target mass for sample processing is $100 \mathrm{mg}$, the actual mass varies from $50 \mathrm{mg}$ to $500 \mathrm{mg}$. This operational mass range yields a minimum sample reporting limit of $0.6 \mathrm{ng} / \mathrm{g}$ to $6 \mathrm{ng} / \mathrm{g}$, as processed.

To demonstrate that the WDML can accurately quantify $\mathrm{HgT}$ in solid samples at environmentally important levels, an MDL study was performed. Even though wet samples were used for this study, the MDL is applicable to both wet and freeze-dried solid samples. The MDL reflects the mass of $\mathrm{Hg}$ in a digestion bomb, and is used to evaluate the mass of $\mathrm{Hg}$ in samples regardless of their condition (wet or freeze-dried) at the time of digestion. 
Table 1. Results from multiple analyses of solids for method detection limit (MDL) assay.

[All masses in nanograms (ng) of mercury per 100 milligrams (mg) of solids]

\begin{tabular}{lc}
\hline & Clay Substrate \\
\hline & 1.39 \\
& 1.53 \\
& 1.73 \\
& 1.55 \\
& 1.60 \\
& 1.40 \\
& 1.43 \\
Average & 1.20 \\
Standard deviation & 1.60 \\
Percent relative standard deviation & 1.42 \\
Detection limit & $\mathbf{1 . 4 9}$ \\
(standard deviation x 2.821*) & $\mathbf{0 . 1}$ \\
\hline *students T-value at the 99 percent confidence interval for $\mathrm{n}=10$
\end{tabular}

*students T-value at the 99 percent confidence interval for $n=10$

An MDL of $0.3 \mathrm{ng}$ of $\mathrm{HgT}$ was determined according to U.S. Environmental Protection Agency (USEPA) protocol (U.S. Environmental Protection Agency, 1990) from multiple analyses of a solid sample that was primarily clay (table 1). The sample was mixed thoroughly, and ten aliquots were transferred into $\mathrm{Hg}$ clean Teflon digestion bombs. The target mass of $100 \mathrm{mg}$ was not achieved for each aliquot; therefore, the mass detected per bomb was converted to a $100 \mathrm{mg}$ equivalency. The samples were analyzed over ten days.

\section{Reagents}

Upon receipt at the laboratory or on the day of preparation, reagent containers should be labeled with the date received or made and the initials of the person preparing them.

A. Reagent water. Ultra-pure reagent grade water containing less than $0.1 \mathrm{ng} / \mathrm{L} \mathrm{Hg}$ with a resistance greater than $18 \mathrm{M} \Omega$-cm starting from a prepurified source (distilled, reverse osmosis, and others). The water is delivered through a $0.2 \mu \mathrm{m}$ filter, as obtained from a Millipore Academic water-purification system or equivalent.
B. Hydrochloric acid (HCl). EM Science Omni Pure $\mathrm{HCl}$ (containing less than $5 \mathrm{ng} / \mathrm{L} \mathrm{Hg}$ ) or equivalent.

C. Bromine monochloride. Dissolve $10.8 \mathrm{~g}$ of reagent grade potassium bromide $(\mathrm{KBr})$ in a $\mathrm{Hg}$ clean Teflon or glass bottle containing $1 \mathrm{~L}$ of concentrated $\mathrm{HCl}$. Place a Teflon coated stir bar into the bottle and stir for 1 hour or until dissolved. Slowly add $15.2 \mathrm{~g}$ reagent grade potassium bromate $\left(\mathrm{KBrO}_{3}\right)$ to the bottle while stirring. $C A U$ TION: This needs to be done slowly and in a fume hood because large quantities of free halogens are produced. Addition of $\mathrm{KBrO}_{3}$ to the solution should produce a color change from yellow to red to orange. Cap bottle loosely and stir for an additional hour. Prepare fresh monthly.

D. Nitric Acid $\left(\mathrm{HNO}_{3}\right)$. EM Science Omni Pure $\mathrm{HNO}_{3}$ (containing less than $5 \mathrm{ng} / \mathrm{L} \mathrm{Hg}$ ) or equivalent.

E. Stannous chloride. Add $30 \mathrm{~g} \mathrm{SnCl}_{2}$ to $50 \mathrm{~mL}$ concentrated $\mathrm{HCl}$ in a dark $2.5 \mathrm{~L}$ glass bottle. Add $950 \mathrm{~mL}$ reagent water. Purge with $\mathrm{Hg}$ free nitrogen $\left(\mathrm{N}_{2}\right)$ at $30 \mathrm{~mL} / \mathrm{min}$ during initial start up and during analysis. Prepare fresh monthly.

F. Hydroxylamine hydrochloride. Dissolve $30 \mathrm{~g}$ of $\mathrm{NH}_{2} \mathrm{OH} * \mathrm{HCl}$ in a Teflon bottle containing $100 \mathrm{~mL}$ reagent water. Add $10 \mu \mathrm{L} \mathrm{SnCl}_{2}$ to the solution and purge with $\mathrm{Hg}$ free $\mathrm{N}_{2}$ at $300 \mathrm{~mL} / \mathrm{min}$ for 1 hour. Prepare fresh every 6 months.

G. Nitrogen. Grade 5.0 (ultra high purity) $\mathrm{N}_{2}$ that is passed through a gold bead trap attached to the outlet of the tank to remove any $\mathrm{Hg}$.

H. Argon (Ar). Grade 5.0 (ultra high purity) Ar that is passed through a gold bead trap attached to the outlet of the tank to remove any $\mathrm{Hg}$.

\section{Standards}

The stock and substock standards should by stored outside of the clean laboratory to prevent contamination of the entire lab. To clean a volumetric flask, fill to approximately 20 percent total volume with 50 percent $\mathrm{HNO}_{3}$, place the ground glass stopper on its side over the opening to prevent pressure buildup, and reflux on a hotplate for 4 hours.

A. Stock standard $\left(1 \times 10^{9} \mathrm{ng} / \mathrm{L}(1000 \mathrm{mg} / \mathrm{L})\right)$. Commercially available $\mathrm{Hg}$ standard verified against an 
NIST standard reference material. All subsequent standards are prepared using the stock standard. Before preparing other standards, ensure the expiration date of the stock standard has not been exceeded.

B. Substock standard $\left(1 \times 10^{6} \mathrm{ng} / \mathrm{L}(1000 \mu \mathrm{g} / \mathrm{L})\right)$. Dispense approximately $50 \mathrm{~mL}$ of reagent grade water and $5 \mathrm{~mL}$ of $\mathrm{BrCl}$ into a $100 \mathrm{~mL} \mathrm{Hg}$ clean class A volumetric flask. Pipette $100 \mu \mathrm{L}$ of the stock standard into the flask and bring to volume with reagent water.

C. Working standard (1000 ng/L). Dispense approximately $500 \mathrm{~mL}$ of reagent grade water and $5 \mathrm{~mL}$ of $\mathrm{BrCl}$ into a $1.0 \mathrm{~L} \mathrm{Hg}$ clean class A volumetric flask. Pipette $1.0 \mathrm{~mL}$ of the substock standard into the flask and bring to volume with reagent water. Prepare fresh every six months.

D. Analytical standards. Analytical standards range from $1 \mathrm{ng} / \mathrm{L}$ to $40 \mathrm{ng} / \mathrm{L}$, and the standards should span the expected concentrations of the samples to be analyzed. Dispense approximately $500 \mathrm{~mL}$ of reagent grade water and $5 \mathrm{~mL}$ of $\mathrm{BrCl}$ into a $1.0 \mathrm{~L}$ $\mathrm{Hg}$ clean class A volumetric flask. Pipette a volume of working standard into the flask that yields the desired concentration of the analytical standard and bring to volume with reagent water. For a $1 \mathrm{ng} / \mathrm{L}$ analytical standard, $1.0 \mathrm{~mL}$ of the working standard would be added. The analytical standard must be compared to the previous analytical standard and agree within \pm five percent. Prepare fresh every six months.

\section{Quality-Control Sample}

The quality-control sample (QCS) will be prepared from a commercially available $\mathrm{Hg}$ standard. The standard will be of a different source or lot than the standard used to prepare the analytical standards. The QCS is used throughout analysis to verify statistical control.

A. Quality-control stock standard $\left(1 \times 10^{10} \mathrm{ng} / \mathrm{L}\right.$ $(10,000 \mathrm{mg} / \mathrm{L}))$. Prepared from NIST standard reference material 3133. All subsequent quality-control standards and samples are prepared using this stock standard. Before preparing other standards, ensure the expiration date of the stock standard has not been exceeded.
B. Quality-control substock standard $\left(1 \times 10^{7} \mathrm{ng} / \mathrm{L}\right.$ $(10,000 \mu \mathrm{g} / \mathrm{L}))$. Dispense approximately $50 \mathrm{~mL}$ of reagent grade water and $5 \mathrm{~mL}$ of $\mathrm{BrCl}$ into a 100 $\mathrm{mL} \mathrm{Hg}$ clean class A volumetric flask. Pipette 100 $\mu \mathrm{L}$ of the quality-control stock standard into the flask and bring to volume with reagent water.

C. Quality-control working standard (1000 ng/L). Dispense approximately $500 \mathrm{~mL}$ of reagent grade water and $5 \mathrm{~mL}$ of $\mathrm{BrCl}$ into a $1.0 \mathrm{~L} \mathrm{Hg}$ clean class A volumetric flask. Pipette $100 \mu \mathrm{L}$ of the qualitycontrol substock standard into the flask and bring to volume with reagent water. Prepare fresh every six months.

D. Quality-control samples. Concentrations for QCS should represent the concentrations of the environmental samples being analyzed. A $5 \mathrm{ng} / \mathrm{L}, 10 \mathrm{ng} / \mathrm{L}$ and $30 \mathrm{ng} / \mathrm{L}$ QCS are used to represent the range of samples encountered. The $5 \mathrm{ng} / \mathrm{L}$ and $10 \mathrm{ng} / \mathrm{L} \mathrm{QCS}$ would be used for lower concentrations, and the 10 ng/L and 30 ng/L QCS would be used for higher concentratoins. Dispense approximately $500 \mathrm{~mL}$ of reagent grade water and $5 \mathrm{~mL} \mathrm{BrCl}$ into a $1.0 \mathrm{~L} \mathrm{Hg}$ clean class A volumetric flask. Pipette the appropriate amount of quality-control working standard into the flask to yield the desired QCS concentration and dilute to volume with reagent water. For a $5 \mathrm{ng} / \mathrm{L}$ QCS, add $5 \mathrm{~mL}$ of the quality-control working standard. The new QCS must be verified against the previous QCS and agree within \pm five percent. A new QCS should be made fresh every six months.

\section{Sample Preparation}

Prior to analysis, solids samples are digested and oxidized to ensure complete conversion of $\mathrm{Hg}$ to $\mathrm{Hg}^{2+}$. Any number of samples may be prepared in a digestion batch. For every 10 environmental samples, there will be a method blank, a CRM sample, and one of the 10 environmental samples will be prepared in triplicate. A minimum of three method blanks must be created for a digestion batch. A method blank is an empty Teflon digestion bomb that has all the reagents added and is carried through all the steps that a sample would undergo.

Solids samples are completely thawed, then thoroughly homogenized using a Teflon policeman. A small aliquot, approximately $100 \mathrm{mg}$, is transferred to a Teflon digestion bomb using the policeman. The exact mass 
transferred is recorded to the nearest tenth of a mg, as well as the bomb ID. When all the solids are transferred to the digestion bombs, $6 \mathrm{~mL}$ of $\mathrm{HCl}$ and $2 \mathrm{~mL}$ of $\mathrm{HNO}_{3}$ are added. This combination of $\mathrm{HCl}$ and $\mathrm{HNO}_{3}$, in a 3:1 ratio, creates aqua regia, a strong oxidizing solution. The bombs are loosely capped and placed in a fume hood for one hour. After the hour has expired, the bombs are then wrench-tightened, and allowed to react overnight at room temperature. After 24 hours, the bombs are diluted with 22 $\mathrm{mL}$ of 5 percent $\mathrm{BrCl}$ to a total volume of $30 \mathrm{~mL}$. When the samples have been diluted, they are wrench-tightened and placed in an oven at $50^{\circ} \mathrm{C}$ overnight, after which time they are ready for analysis.

\section{Sample Analysis}

After the digestion bombs are removed from the oven, the digestate is thoroughly mixed, an aliquot is transferred to a $60-\mathrm{mL}$ Teflon vial containing $50 \mu \mathrm{L} \mathrm{NH}_{2} \mathrm{OH}^{*} \mathrm{HCl}$, and diluted to $50 \mathrm{~mL}$. These diluted samples are then analyzed according to USEPA Method 1631, Revision E (U.S. Environmental Protection Agency, 2002) utilizing an automated flow injection system. An analytical batch consists of 12 vials bracketed by the appropriate high level and low level QCS. Eleven vials contain samples, and the twelfth vial is a matrix spike of an environmental sample contained in one of the previous 11 vials. All samples are analyzed in duplicate from their respective vials and must fall within the calibration range. If they do not, they must be diluted further in a fresh 60-mL Teflon vial. A sample can consist of a method blank, a CRM, or an environmental sample.

\section{Data Quality Objectives}

Data Quality Objectives (DQOs) have been established to evaluate statistical control over the analytical system during the analysis.

A. Correlation coefficient. The correlation coefficient of the standard curve using a simple linear regression forcing zero must be 0.995 or greater. If the standard curve does not meet the objective, the system is deemed out of control, and sample analysis cannot proceed. The issue must be resolved, and an acceptable standard curve needs to be generated before analyzing samples.

B. Quality-control samples. The analytically determined QCS concentrations must have a percent recovery of 90 to 110 percent when compared to the actual concentration. If either QCS fails to meet criteria, the samples that were bracketed must be reanalyzed until they are bracketed by acceptable QCS or until volume is exhausted. If no sample volume remains and either bracketing QCS does not meet the DQO, then the environmental samples in that batch must be prepared again if the remaining sample mass is sufficient. If the sample cannot be prepared again, the samples are flagged with a quality assurance (QA) flag, indicating failure of QCS during analysis.

$\mathrm{R}_{\mathrm{QCS}}=\left(\mathrm{C}_{\mathrm{A}} / \mathrm{C}_{\mathrm{T}}\right) * 100$,

where

$\mathrm{R}_{\mathrm{QCS}}=$ percent recovery for the QCS

$\mathrm{C}_{\mathrm{A}}=$ Analytically determined concentration of the

QCS, in $n g / L$

$\mathrm{C}_{\mathrm{T}}=$ Theoretical concentration of the QCS, in $\mathrm{ng} / \mathrm{L}$

C. Duplicate analysis. The percent difference between duplicate analyses taken from the same vial for a sample must be less than 10 percent. If the percent difference for the sample is greater than 10 percent, the sample must be rerun if volume permits. If the sample cannot be analyzed again, that specific sample must be prepared again if the remaining sample mass is sufficient. If the sample cannot be prepared again, the sample is flagged with a QA flag indicating a percent difference failure.

$\%$ Diff $=\left|C_{1}-C_{2}\right| / C_{A V E} * 100$,

where

$\%$ Diff = Percent difference for duplicate analysis

$\mathrm{C}_{1}=$ Concentration of digestate for first sample analysis, in $\mathrm{ng} / \mathrm{L}$

$\mathrm{C}_{2}=$ Concentration of digestate for second sample analysis, in $\mathrm{ng} / \mathrm{L}$

$\mathrm{C}_{\mathrm{AVE}}=$ Average concentration of both analyses, in $\mathrm{ng} / \mathrm{L}$

D. Matrix spikes. One sample in the analytical batch is spiked with a known amount of $\mathrm{Hg}$. The percent recovery of the spike must be 90 to 110 percent. If the matrix spike does not meet criteria, another matrix spike is run on that sample, volume permitting, as well as another sample. If the new matrix spikes do not meet criteria, the batch is flagged with a QA flag indicating a potential matrix interference problem with the samples. 


$$
\mathrm{R}_{\mathrm{SP}}=\left(\mathrm{C}_{\mathrm{SP}}-\mathrm{C}_{\mathrm{UN}}\right) /\left(\mathrm{S}_{\mathrm{M}} / \mathrm{V}\right) * 100,
$$

where

$\mathrm{R}_{\mathrm{SP}}=$ Percent recovery for matrix spike

$\mathrm{C}_{\mathrm{SP}}=$ Concentration of the spiked sample, in $\mathrm{ng} / \mathrm{L}$

$\mathrm{C}_{\mathrm{UN}}=$ Concentration of the unspiked sample, in $\mathrm{ng} / \mathrm{L}$

$\mathrm{S}_{\mathrm{M}}=$ Mass of the spike, in ng

$\mathrm{V}=$ Total volume in autosampler vial, in $\mathrm{L}$

\section{Analytical Equipment}

A. Regulator capable of supplying 30 pounds per square inch (psi) of pressure.

B. Detector. The detector is a commercially available Model 2600 CVAFS mercury detector from Tekran (Toronto, ON) equipped with a mass flow controller capable of measuring $30 \mathrm{~mL} / \mathrm{min}$ and an auxiliary flow meter capable of measuring $300 \mathrm{~mL} / \mathrm{min}$.

C. Autosampler. The Model 2630 automatic sample changer from Tekran holds four racks of $1260-\mathrm{mL}$ autosampler vials and contains a rinse station.

D. Peristaltic pump. The Model 2610 peristaltic pump from Tekran flushes the rinse station and pumps sample, reagents, and rinse water to the gas/liquid separator. The pump also removes waste from the gas/liquid separator and overflow from the rinse station.

E. Gold-coated glass bead trap. The gold-coated glass bead trap is constructed of a 7-mm outside diameter (O.D.) quartz tube, $10 \mathrm{~cm}$ long and with a constriction $3 \mathrm{~cm}$ from the outlet end. A plug of quartz wool is placed into the inlet end, about 0.7 $\mathrm{g}$ (filling about $3.5 \mathrm{~cm}$ in the tube) of gold-coated glass beads are added, and the inlet end is plugged with another piece of quartz wool. After the traps are packed, another constriction is added at the inlet end. Female fittings for gold traps are made from small pieces of 6-mm inside diameter (I.D.) monobarb Teflon tubing.

F. Soda lime trap. The soda lime trap is supplied with the Tekran Model 2600 CVAFS mercury detector. The trap is filled with 4-8 mesh soda lime. The soda lime trap captures moisture and free halogens that are generated by purging the sample. The soda lime trap removes these constituents before they can reach the gold trap. Moisture will create interferences with the $\mathrm{Hg}$ detector and free halogens will destroy the gold trap.

G. Rinse water reservoir. 5-L Teflon carboy filled with reagent water and acidified to 1 percent with $\mathrm{HCl}$.

H. Stannous chloride reservoir. $\mathrm{SnCl}_{2}$ solution is placed into a dark 2.5-L glass bottle and slowly purged with $\mathrm{N}_{2}$ throughout the analysis.

\section{Data Analysis}

The following formulas are used to calculate concentrations.

\section{CONCENTRATION OF DIGESTATE}

$$
\mathrm{C}_{\mathrm{ng} / \mathrm{L}}=(\mathrm{PA} / \mathrm{S}) * \mathrm{D},
$$

where

$\mathrm{C}_{\mathrm{ng} / \mathrm{L}}=$ concentration of digestate, in $\mathrm{ng} / \mathrm{L}$

$\mathrm{PA}=$ peak area

$\mathrm{S}=$ slope of calibration line

$\mathrm{D}=$ dilution factor $(50 /$ sample aliquot volume in $\mathrm{mL})$

\section{MASS OF Hg IN METHOD BLANK}

$$
\mathrm{M}_{\mathrm{BB}}=\mathrm{C}_{\mathrm{ng} / \mathrm{L}} * \mathrm{~V}_{\mathrm{B}},
$$

where

$\mathrm{M}_{\mathrm{BB}}=$ mass of $\mathrm{Hg}$ in method blank, in ng

$\mathrm{C}_{\mathrm{ng} / \mathrm{L}}=$ concentration of digestate, in $\mathrm{ng} / \mathrm{L}$, as determined in Equation 4

$\mathrm{V}_{\mathrm{B}}=$ volume of digestate originally in bomb, in $\mathrm{L}$

MASS OF Hg IN BOMB FROM SAMPLE

$$
\mathrm{M}_{\mathrm{S}}=\left(\mathrm{C}_{\mathrm{ng} / \mathrm{L}} * \mathrm{~V}_{\mathrm{B}}\right)-\mathrm{M}_{\mathrm{BB}-\mathrm{AVE}},
$$

where

$\mathrm{M}_{\mathrm{S}}=$ mass of $\mathrm{Hg}$ in sample bomb, in ng

$\mathrm{C}_{\mathrm{ng} / \mathrm{L}}=$ concentration of digestate, in $\mathrm{ng} / \mathrm{L}$, as determined in Equation 4

$\mathrm{V}_{\mathrm{B}}=$ volume of digestate originally in bomb, in $\mathrm{L}$

$\mathrm{M}_{\mathrm{BB}-\mathrm{AVE}}=$ average mass in all method blanks for digestion batch 
ng/g CONCENTRATION OF SOLIDS SAMPLE

$$
\mathrm{C}_{\mathrm{ng} / \mathrm{g}}=\mathrm{M}_{\mathrm{s}} / \mathrm{W}_{\mathrm{s}}
$$

where

$\mathrm{C}_{\mathrm{ng} / \mathrm{g}}=$ concentration of sample, in $\mathrm{ng} / \mathrm{g}$

$\mathrm{M}_{\mathrm{S}}=$ mass of $\mathrm{Hg}$ in sample bomb, in $\mathrm{ng}$

$\mathrm{W}_{\mathrm{S}}=$ mass of solids in bomb, in $\mathrm{g}$

\section{Acceptance Criteria}

Included with the digestion batch of environmental samples are method blanks, replicate analyses, and CRM samples. Each of these samples provides quality-control information used to evaluate the acceptability of the analytical runs. Typically, multiple analytical runs are necessary to analyze the entire digestion batch.

A. Method blanks. Method blanks are included in each digestion batch, with a minimum of 3 blanks per day of sample preparation. The method blanks are used to evaluate gross contamination and to correct for background $\mathrm{Hg}$ from reagents during digestion, oxidation, and analysis. Values obtained from these blanks are used to calculate a batch detection limit (BDL) for the digestion batch. The DQO for BDL is $0.3 \mathrm{ng}$.

$\mathrm{BDL}=3 * \sigma$,

where

$\mathrm{BDL}=$ Batch detection limit

$\sigma=$ Standard deviation of the method blanks for the digestion batch, in ng

B. Replicate analyses. One sample from each batch is prepared in triplicate to evaluate the precision of the method. DQOs for replicate analyses are a relative standard deviation of no more than 25 percent.

C. Certified reference material. There are CRM samples included in each batch that are used to evaluate the accuracy of the analytical run. DQOs for CRMs are 80 to 120 percent recovery.

\section{Method Performance}

To evaluate method performance, three separate solids samples were analyzed over 10 days, representing different types of materials. One was a predominately clay substrate, the second was an organic rich substrate, and the third was a sandy, mineral substrate. Each sample was set up in 20 separate bombs, with half of those having a
Table 2. Total mercury concentrations for multiple analyses of clay substrate and organic substrate solids samples

[All concentrations in nanograms per gram (ng/g) wet weight]

\begin{tabular}{lcc}
\hline & $\begin{array}{c}\text { Clay } \\
\text { Substrate }\end{array}$ & $\begin{array}{c}\text { Organic } \\
\text { Substrate }\end{array}$ \\
\hline & 13.9 & 12.6 \\
15.3 & 10.1 \\
& 17.3 & 12.5 \\
& 15.5 & 13.0 \\
& 16.0 & 11.4 \\
& 14.0 & 11.4 \\
& 14.3 & 11.9 \\
& 12.0 & 11.9 \\
& 16.0 & 16.0 \\
\hline Average & 14.2 & 11.3 \\
Standard deviation & $\mathbf{1 4 . 9}$ & $\mathbf{1 2 . 2}$ \\
Percent relative standard & $\mathbf{1 . 5}$ & $\mathbf{1 . 6}$ \\
deviation & & \\
\hline
\end{tabular}

$1 \mathrm{ng} \mathrm{Hg}$ spike added to them to evaluate the digestion and oxidation processes.

Precision was evaluated by examining the percent relative standard deviation of the concentrations obtained from all analyses of the solid samples for each type of material. The percent relative standard deviation for the clay substrate was 10.0 and the organic rich substrate was 12.8 (table 2). The sand substrate was not used to evaluate precision because the concentration of the samples was less than the MDL. Percent relative standard deviation was calculated using the formula:

\section{PERCENT RELATIVE STANDARD DEVIATION}

$$
\% \mathrm{RSD}=\left(\mathrm{C}_{\mathrm{STDEV}} / \mathrm{C}_{\mathrm{AVE}}\right) * 100
$$

where

$$
\begin{aligned}
& \% \mathrm{RSD}=\text { percent relative standard deviation } \\
& \mathrm{C}_{\mathrm{STDEV}}=\text { standard deviation of all samples } \\
& \mathrm{C}_{\mathrm{AVE}}=\text { average concentration of all samples }
\end{aligned}
$$

Accuracy was evaluated by calculating the percent recovery for the matrix spikes versus the unspiked samples. All three substrates were used to evaluate accuracy because a known amount of $\mathrm{Hg}$ was added to the digestion bomb and a recovery could be based on that addition. Percent recoveries were calculated using the formula: 


\section{PERCENT RECOVERY}

$$
\mathrm{R}=\left(\left(\mathrm{M}_{\mathrm{S}}-\left(\mathrm{C}_{\mathrm{A}} * \mathrm{~W}_{\mathrm{S}}\right)\right) / \mathrm{S}_{\mathrm{M}}\right) * 100,
$$

where

$\mathrm{R}=$ percent recovery

$\mathrm{M}_{\mathrm{S}}=$ analytically determined mercury mass in aliquot

$\mathrm{C}_{\mathrm{A}}=$ average concentration of unspiked sample

$\mathrm{W}_{\mathrm{S}}=$ mass of sample aliquot

$\mathrm{S}_{\mathrm{M}}=$ mass of spike added

Recoveries ranged from 75 to 176 percent with an average of 113 and a standard deviation of 31 for the clay substrate sample (table 3 ). For the organic substrate sample, only four samples could be evaluated for accuracy due to operational problems encountered. The identification codes were in question for six of the bombs; therefore, the mass of the sample aliquots were uncertain for those samples, and spike recoveries could not be positively calculated. Based on the four samples that were not in question, recoveries ranged from 77 to 90 percent with an average of 85 and a standard deviation of 6 . The percent recoveries for the sand substrate ranged from 89 to 104 percent, with an average of 97 and a standard deviation of 5 .

Table 3. Percent recovery data for the clay substrate, organic substrate, and sand substrate solids samples. Each sample was spiked with 1 nanogram of mercury.

\begin{tabular}{lccc}
\hline & $\begin{array}{c}\text { Percent } \\
\text { Recovery } \\
\text { Clay } \\
\text { Substrate }\end{array}$ & $\begin{array}{c}\text { Percent } \\
\text { Recovery } \\
\text { Organic } \\
\text { Substrate }\end{array}$ & $\begin{array}{c}\text { Percent } \\
\text { Recovery } \\
\text { Sand } \\
\text { Substrate }\end{array}$ \\
\hline 118 & & 99 \\
91 & & 93 \\
132 & & 97 \\
& 144 & & 98 \\
& 79 & & 89 \\
& 176 & & 104 \\
& 102 & 88 & 95 \\
& 99 & 77 & 92 \\
& 111 & 84 & 98 \\
\hline Average & 75 & 90 & 101 \\
Standard deviation & $\mathbf{1 1 3}$ & $\mathbf{8 5}$ & $\mathbf{9 7}$ \\
\hline
\end{tabular}

\section{Part 2. Method for the Oxidation and Analysis of Total Mercury in Suspended Solids}

\section{Scope and Application}

This method is suitable for the determination of $\mathrm{HgT}$ in suspended solids isolated onto pre-baked quartz fiber filters (QFF). The minimum sample mass detectable is 0.059 ng and the range can be extended to meet most samples by controlling the amount of water filtered through the QFF and through dilutions of the oxidized sample. All samples are reported in $\mathrm{ng} / \mathrm{L}$.

\section{Method Summary}

Particulate samples collected onto baked quartz fiber filters are oxidized with $\mathrm{BrCl}$ to convert all forms of $\mathrm{Hg}$ to $\mathrm{Hg}^{2+}$. After oxidation, the sample is pre-reduced with $\mathrm{NH}_{2} \mathrm{OH}^{*} \mathrm{HCl}$ to remove the free halogens, then reduced with $\mathrm{SnCl}_{2}$ to convert $\mathrm{Hg}^{2+}$ to $\mathrm{Hg}^{0}$. The $\mathrm{Hg}^{0}$ is purged, captured on a gold trap, then thermally desorbed and detected using a CVAFS. This method can be used to determine $\mathrm{HgT}$ concentrations in particulate samples with a MDL of $0.059 \mathrm{ng}$ of $\mathrm{Hg}$ on a filter. The amount of $\mathrm{Hg}$ on a filter is dependent on the solids load in the sample and volume of sample filtered.

\section{Sample Collection and Preservation}

To provide reliable concentrations for $\mathrm{HgT}$ in suspended solids, the WDML has developed a method to concentrate suspended solids from unfiltered water by either in-line filtration or by vacuum filtration. In either case, samples should be collected using clean hands/dirty hands sampling protocols (Olson and DeWild, 1999) to ensure sample integrity. Sample size is dependent on suspended particulate load and $\mathrm{HgT}$ concentration, but generally ranges from 0.5 to 1 liter. The suspended solids are retained on baked (prepared by heating to $550^{\circ} \mathrm{C}$ for four hours) QFF. To provide HgT concentrations for suspended solid samples in mass per unit volume (for example, ng/L), field crews must measure and record the volume of water filtered. Individual filters are placed into stackable Teflon petri dishes, double bagged in sealable plastic bags, and frozen. Samples are shipped to the lab on dry ice by overnight mail, and held frozen at a temperature of $-15^{\circ} \mathrm{C}$ or less until processing. The WDML has not performed a 
holding time study; however, a frozen CRM certified for $\mathrm{Hg}$ is available through NIST and is stable for a duration of 9 years.

\section{Method Detection Limit}

Samples are reported in $\mathrm{ng} / \mathrm{L}$. The $\mathrm{ng} / \mathrm{L}$ concentration can be converted to $\mathrm{ng} / \mathrm{g}$ if the mass of particles per volume of water is also determined. The $\mathrm{ng} / \mathrm{L}$ concentration can also be combined with the $\mathrm{ng} / \mathrm{L}$ concentration of the corresponding filtered water sample to obtain an estimate of the whole water $\mathrm{Hg}$ concentration. In hydrologic systems that are low in suspended solids, the filtered and whole water $\mathrm{Hg}$ concentrations can be indistinguishable within the limits of detection. The ability to separate and concentrate the suspended solids increases the ability to accurately evaluate the difference between the filtered and whole waters.

Suspended particulate loads vary considerably within hydrologic settings; therefore, varying amounts of sample water need to be filtered to obtain an appropriate amount of material for analysis. Using an MDL based on mass per filter allows a direct comparison of the amount of mercury in the oxidized sample solution to the consistent value of $0.059 \mathrm{ng}$ rather than a constantly changing MDL expressed in $\mathrm{ng} / \mathrm{L}$ based on the volume of sample water filtered. The volume of water filtered varies from $0.050 \mathrm{~L}$ to $1.0 \mathrm{~L}$, and this range provides a minimum sample reporting limit varying from $0.059 \mathrm{ng} / \mathrm{L}$ to $1.18 \mathrm{ng} / \mathrm{L}$.

To demonstrate that the WDML can accurately quantify $\mathrm{HgT}$ in particulate samples at or below environmentally important levels, an MDL study was performed. An MDL of $0.059 \mathrm{ng}$ of $\mathrm{HgT}$ per filter was determined from multiple analyses of a CRM that was suspended in reagent water and filtered onto 10 separate QFFs (table 4). A mass of $0.0502 \mathrm{~g}$ of the CRM (MESS-2 marine sediment) was added to $2.0 \mathrm{~L}$ of reagent water. A subsample of the slurry was poured into a $\mathrm{Hg}$ clean Teflon bottle after thorough mixing. The remaining slurry was then mixed and filtered onto baked QFFs that were frozen until oxidation. Some of the filtrate was also collected into a clean Teflon bottle. The samples were analyzed over five days. The unfiltered and filtered water samples were analyzed during a single analysis run. For this study, the target volume per filter was $100.0 \mathrm{~mL}$. This volume was not accurately achieved for each filter; therefore, the analytically determined mass per filter was converted to a $100.0 \mathrm{~mL}$ equivalency to accurately determine a mass-based MDL.
Table 4. Results from multiple analyses of particulate MESS-2 CRM for detection limit assay

[all masses in ng per $100.0 \mathrm{~mL}$ of slurry]

\begin{tabular}{lc}
\hline & Particulate CRM \\
\hline & 0.201 \\
& .208 \\
& .177 \\
& .184 \\
& .164 \\
& .152 \\
& .141 \\
& .169 \\
Average & .176 \\
Percent relative standard deviation & .187 \\
Detection limit & $\mathbf{. 1 7 6}$ \\
(standard deviation x 2.821*) & $\mathbf{. 0 2 1}$ \\
\hline
\end{tabular}

*students T-value at the 99 percent confidence interval for $\mathrm{n}=10$

\section{Reagents}

Upon receipt at the laboratory or on the day of preparation, reagent containers should be labeled with the date received or made and the initials of the person preparing them.

A. Reagent water. Ultra-pure reagent grade water containing less than $0.1 \mathrm{ng} / \mathrm{L} \mathrm{Hg}$ with a resistance greater than $18 \mathrm{M} \Omega$-cm starting from a prepurified source (distilled, reverse osmosis, and others). The water is delivered through a $0.2 \mu \mathrm{m}$ filter, as obtained from a Millipore Academic water-purification system or equivalent.

B. Hydrochloric acid. EM Science Omni Pure $\mathrm{HCl}$ (containing less than $5 \mathrm{ng} / \mathrm{L} \mathrm{Hg}$ ) or equivalent.

C. Bromine monochloride. Dissolve $10.8 \mathrm{~g}$ of reagent grade $\mathrm{KBr}$ in a $\mathrm{Hg}$ clean Teflon or glass bottle containing $1 \mathrm{~L}$ of concentrated $\mathrm{HCl}$. Place a Teflon coated stir bar into the bottle and stir for one hour or until dissolved. Slowly add $15.2 \mathrm{~g}$ reagent grade $\mathrm{KBrO}_{3}$ to the bottle while stirring. $C A U$ TION: This needs to be done slowly and in a fume hood because large quantities of free halogens are produced. Addition of $\mathrm{KBrO}_{3}$ to the solution 
should produce a color change from yellow to red to orange. Cap bottle loosely and stir for an additional hour. Prepare fresh monthly.

D. Stannous chloride. Add $30 \mathrm{~g} \mathrm{SnCl}$ to $50 \mathrm{~mL}$ concentrated $\mathrm{HCl}$ in a dark $2.5 \mathrm{~L}$ glass bottle. Add $950 \mathrm{~mL}$ reagent water. Purge with $\mathrm{Hg}$ free $\mathrm{N}_{2}$ at 30 $\mathrm{mL} / \mathrm{min}$ during initial start up and during analysis. Prepare fresh monthly.

E. Hydroxylamine hydrochloride. Dissolve $30 \mathrm{~g}$ of $\mathrm{NH}_{2} \mathrm{OH}^{*} \mathrm{HCl}$ in a Teflon bottle containing $100 \mathrm{~mL}$ reagent water. Add $10 \mu \mathrm{L} \mathrm{SnCl}_{2}$ to the solution and purge with $\mathrm{Hg}$ free $\mathrm{N}_{2}$ at $300 \mathrm{~mL} / \mathrm{min}$ for 1 hour. Prepare fresh every six months.

F. Nitrogen. Grade 5.0 (ultra high purity) $\mathrm{N}_{2}$ that is passed through a gold bead trap attached to the outlet of the tank to remove any $\mathrm{Hg}$.

G. Argon. Grade 5.0 (ultra high purity) Ar that is passed through a gold bead trap attached to the outlet of the tank to remove any $\mathrm{Hg}$.

\section{Standards}

The stock and substock standards should be stored outside of the clean laboratory to prevent contamination of the entire lab. To clean a volumetric flask, fill to approximately 20 percent total volume with 50 percent $\mathrm{HNO} 3$, place the ground glass stopper on its side over the opening to prevent pressure buildup, and reflux on a hotplate for 4 hours.

A. Stock standard $\left(1 \times 10^{9} \mathrm{ng} / \mathrm{L}(1000 \mathrm{mg} / \mathrm{L})\right)$. Commercially available $\mathrm{Hg}$ standard verified against a NIST standard reference material. All subsequent standards are prepared using the stock standard. Before preparing other standards, ensure the expiration date of the stock standard has not been exceeded.

B. Substock standard $\left(1 \times 10^{6} \mathrm{ng} / \mathrm{L}(1000 \mu \mathrm{g} / \mathrm{L})\right)$. Dispense approximately $50 \mathrm{~mL}$ of reagent grade water and $5 \mathrm{~mL}$ of $\mathrm{BrCl}$ into a $100 \mathrm{~mL} \mathrm{Hg}$ clean class A volumetric flask. Pipette $100 \mu \mathrm{L}$ of the stock standard into the flask and bring to volume with reagent water.

C. Working standard (1000 ng/L). Dispense approximately $500 \mathrm{~mL}$ of reagent grade water and $5 \mathrm{~mL}$ of $\mathrm{BrCl}$ into a $1.0 \mathrm{~L} \mathrm{Hg}$ clean class A volumetric flask. Pipette $1.0 \mathrm{~mL}$ of the substock standard into the flask and bring to volume with reagent water. Prepare fresh every six months.

D. Analytical standards. Analytical standards range from $1 \mathrm{ng} / \mathrm{L}$ to $40 \mathrm{ng} / \mathrm{L}$, and the standards should span the expected concentrations of the samples to be analyzed. Dispense approximately $500 \mathrm{~mL}$ of reagent grade water and $5 \mathrm{~mL}$ of $\mathrm{BrCl}$ into a $1.0 \mathrm{~L}$ $\mathrm{Hg}$ clean class A volumetric flask. Pipette a volume of working standard into the flask that yields the desired concentration of the analytical standard and bring to volume with reagent water. For a $1 \mathrm{ng} / \mathrm{L}$ analytical standard, $1.0 \mathrm{~mL}$ of the working standard would be added. The analytical standard must be compared to the previous analytical standard and agree within \pm five percent. Prepare fresh every six months.

\section{Quality-Control Sample}

The QCS will be prepared from a commercially available $\mathrm{Hg}$ standard. The standard will be of a different source or lot than the standard used to prepare the analytical standards. The QCS is used throughout analysis to verify statistical control.

A. Quality-control stock standard $\left(1 \times 10^{10} \mathrm{ng} / \mathrm{L}\right.$ $(10,000 \mathrm{mg} / \mathrm{L}))$. Prepared from NIST standard reference material 3133. All subsequent quality-control standards and samples are prepared using this stock standard. Before preparing other standards, ensure the expiration date of the stock standard has not been exceeded.

B. Quality-control substock standard $\left(1 \times 10^{7} \mathrm{ng} / \mathrm{L}\right.$ $(10,000 \mu \mathrm{g} / \mathrm{L}))$. Dispense approximately $50 \mathrm{~mL}$ of reagent grade water and $5 \mathrm{~mL}$ of $\mathrm{BrCl}$ into a 100 $\mathrm{mL} \mathrm{Hg}$ clean class A volumetric flask. Pipette 100 $\mu \mathrm{L}$ of the quality-control stock standard into the flask and bring to volume with reagent water.

C. Quality-control working standard (1000 ng/L). Dispense approximately $500 \mathrm{~mL}$ of reagent grade water and $5 \mathrm{~mL}$ of $\mathrm{BrCl}$ into a $1.0 \mathrm{~L} \mathrm{Hg}$ clean class A volumetric flask. Pipette $100 \mu \mathrm{L}$ of the qualitycontrol substock standard into the flask and bring to volume with reagent water. Prepare fresh every six months. 
D. Quality-control samples. Concentrations for QCS should represent the concentrations of the environmental samples being analyzed. A $5 \mathrm{ng} / \mathrm{L}, 10 \mathrm{ng} / \mathrm{L}$, and $30 \mathrm{ng} / \mathrm{L}$ QCS are used to represent the range of samples encountered. The $5 \mathrm{ng} / \mathrm{L}$ and $10 \mathrm{ng} / \mathrm{L}$ QCS would be used for lower concentrations, and the $10 \mathrm{ng} / \mathrm{L}$ and $30 \mathrm{ng} / \mathrm{L}$ QCS would be used for higher concentrations. Dispense approximately $500 \mathrm{~mL}$ of reagent grade water and $5 \mathrm{~mL} \mathrm{BrCl}$ into a $1.0 \mathrm{~L} \mathrm{Hg}$ clean class A volumetric flask. Pipette the appropriate amount of quality-control working standard into the flask to yield the desired QCS concentration and dilute to volume with reagent water. For a $5 \mathrm{ng} / \mathrm{L}$ QCS, add $5 \mathrm{~mL}$ of the quality-control working standard. The new QCS must be verified against the previous QCS and agree within \pm five percent. A new QCS should be made fresh every six months.

\section{Sample Preparation}

Filters to be analyzed for $\mathrm{HgT}$ are thawed and placed into a 125 -mL wide-mouth $\mathrm{Hg}$ clean Teflon bottles using a Teflon forceps. The Teflon petri dishes are rinsed three times with 5 percent $\mathrm{BrCl}$ into the sample bottle then the volume is brought up to $100.0 \mathrm{~mL}$ with the same 5 percent $\mathrm{BrCl}$ that was used for rinsing the petri dishes. The petri dish ID's are recorded and matched to the sample bottle ID that will now be used to track the sample through analysis. A method blank and a CRM are included with every ten samples, and a minimum of three blanks are included in each preparation batch. The preparation batch is all the samples that were prepared that day. A method blank includes a baked QFF and $100.0 \mathrm{~mL}$ of the 5 percent $\mathrm{BrCl}$. A CRM is prepared by adding a measured mass of CRM to a $125 \mathrm{~mL}$ wide mouth $\mathrm{Hg}$ clean Teflon bottle and adding $100.0 \mathrm{~mL}$ of the 5 percent $\mathrm{BrCl}$. The samples are capped tightly, double bagged and placed into an oven at $50^{\circ} \mathrm{C}$ for five days.

\section{Sample Analysis}

After oxidation, the samples are cooled, mixed, and $50 \mathrm{~mL}$ of sample is poured into a $60-\mathrm{mL}$ Teflon vial containing $50 \mu \mathrm{L}$ of $\mathrm{NH}_{2} \mathrm{OH}^{*} \mathrm{HCl}$. The samples are analyzed according to USEPA Method 1631, Revision E (U.S. Environmental Protection Agency, 2002) utilizing an automated flow injection system. An analytical batch consists of 12 samples and is bracketed by the appropriate high level and low level QCS. All samples must fall within the calibration range. If they do not, they must be diluted appropriately. A sample can consist of a method blank, a CRM, or an environmental sample.

\section{Data Quality Objectives}

DQOs have been established to evaluate statistical control over the analytical system during the analysis.

A. Correlation coefficient. The correlation coefficient of the standard curve using a simple linear regression forcing zero must be 0.995 or greater. If the standard curve does not meet the objective, the system is deemed out of control, and sample analysis cannot proceed. The issue must be resolved, and an acceptable standard curve needs to be generated before analyzing samples.

B. Quality-control samples. The analytically determined QCS concentrations must have a percent recovery of 90 to 110 percent as compared to the actual concentration. If either QCS fails to meet criteria, the samples that were bracketed must be reanalyzed until they are bracketed by acceptable QCS or until volume is exhausted. If no sample volume remains and either bracketing QCS does not meet the DQO, then the batch must be flagged with a QA flag indicating QCS failure.

$\mathrm{R}_{\mathrm{QCS}}=\left(\mathrm{C}_{\mathrm{A}} / \mathrm{C}_{\mathrm{T}}\right) * 100$,

where

$\mathrm{R}_{\mathrm{QCS}}=$ percent recovery for the QCS

$\mathrm{C}_{\mathrm{A}}=$ Analytically determined concentration of the QCS, in $\mathrm{ng} / \mathrm{L}$

$\mathrm{C}_{\mathrm{T}}=$ Theoretical concentration of the QCS, in $\mathrm{ng} / \mathrm{L}$

\section{Analytical Equipment}

A. Regulator capable of supplying $30 \mathrm{psi}$ of pressure.

B. Detector. The detector is a commercially available Model 2600 CVAFS mercury detector from Tekran equipped with a mass flow controller capable of measuring $30 \mathrm{~mL} / \mathrm{min}$ and an auxiliary flow meter capable of measuring $300 \mathrm{~mL} / \mathrm{min}$.

C. Autosampler. The Model 2630 automatic sample changer from Tekran holds 4 racks of $1260-\mathrm{mL}$ autosampler vials and contains a rinse station. 
D. Peristaltic pump. The Model 2610 peristaltic pump from Tekran flushes the rinse station and pumps sample, reagents, and rinse water to the gas/liquid separator. The pump also removes waste from the gas/liquid separator and overflow from the rinse station.

E. Gold-coated glass bead trap. The gold-coated glass bead trap is constructed of a 7-mm O.D. quartz tube, $10 \mathrm{~cm}$ long and with a constriction 3 $\mathrm{cm}$ from the outlet end. A plug of quartz wool is placed into the inlet end, about $0.7 \mathrm{~g}$ (filling about $3.5 \mathrm{~cm}$ in the tube) of gold-coated glass beads are added, and the inlet end is plugged with another piece of quartz wool. After the traps are packed, another constriction is added at the inlet end. Female fittings for gold traps are made from small pieces of 6-mm I.D. monobarb Teflon tubing.

F. Soda lime trap. The soda lime trap is supplied with the Tekran Model 2600 CVAFS mercury detector. The trap is filled with 4-8 mesh soda lime. The soda lime trap captures moisture and free halogens that are generated by purging the sample. The soda lime trap removes these constituents before they can reach the gold trap. Moisture will create interferences with the $\mathrm{Hg}$ detector and free halogens will destroy the gold trap.

G. Rinse water reservoir. 5-L Teflon carboy filled with reagent water and acidified to 1 percent with $\mathrm{HCl}$.

H. Stannous chloride reservoir. $\mathrm{SnCl}_{2}$ solution is placed into a dark $2.5-\mathrm{L}$ glass bottle and slowly purged with $\mathrm{N}_{2}$ throughout the analysis.

\section{Data Analysis}

The following formulas are used to determine the amount of $\mathrm{Hg}$ in $\mathrm{ng} / \mathrm{L}$ from the original sample.

\section{CONCENTRATION OF OXIDIZED SOLUTION}

$$
\mathrm{C}_{\mathrm{Ox}}=\mathrm{PA} / \mathrm{S} \text {, }
$$

where

$\mathrm{C}_{\mathrm{Ox}}=$ concentration of oxidized solution, in $\mathrm{ng} / \mathrm{L}$

$\mathrm{PA}=$ peak area

$\mathrm{S}=$ slope of calibration line

\section{MASS OF Hg IN METHOD BLANK}

$$
\mathrm{M}_{\mathrm{FB}}=\mathrm{C}_{\mathrm{Ox}} * \mathrm{~V}_{\mathrm{B}},
$$

where

$\mathrm{M}_{\mathrm{FB}}=$ mass of $\mathrm{Hg}$ in method blank, in $\mathrm{ng}$

$\mathrm{C}_{\mathrm{Ox}}=$ concentration of oxidized solution, in $\mathrm{ng} / \mathrm{L}$, as determined in Equation 11

$V_{B}=$ volume of sample originally in bottle, in $L$

MASS OF Hg ON FILTER

$$
\mathrm{M}_{\mathrm{F}}=\left(\mathrm{C}_{\mathrm{Ox}} * \mathrm{~V}_{\mathrm{B}}\right)-\mathrm{M}_{\mathrm{FB}-\mathrm{AVE}},
$$

where

$\mathrm{M}_{\mathrm{F}}=$ mass of $\mathrm{Hg}$ on filter, in $\mathrm{ng}$

$\mathrm{C}_{\mathrm{Ox}}=$ concentration of oxidized solution, in $\mathrm{ng} / \mathrm{L}$, as determined in Equation 11

$\mathrm{V}_{\mathrm{B}}$ = volume of sample originally in bottle, in $\mathrm{L}$

$\mathrm{M}_{\mathrm{FB}-\mathrm{AVE}}=$ average mass of $\mathrm{Hg}$ in all method blanks, in ng

ng/L CONCENTRATION OF SUSPENDED SOLIDS SAMPLE

$$
\mathrm{C}_{\mathrm{P}}=\mathrm{M}_{\mathrm{F}} / \mathrm{V}_{\mathrm{F}},
$$

where

$\mathrm{C}_{\mathrm{P}}=$ concentration of sample, in $\mathrm{ng} / \mathrm{L}$

$\mathrm{M}_{\mathrm{F}}=$ mass of $\mathrm{Hg}$ on filter, in $\mathrm{ng}$

$\mathrm{V}_{\mathrm{F}}=$ volume of water that passed through filter, in $\mathrm{L}$

\section{Acceptance Criteria}

Included with the preparation batch of environmental samples are method blanks and CRM samples. Each of these samples provides quality-control information used to evaluate the acceptability of the analytical runs. Typically, multiple analytical runs are necessary to analyze the entire preparation batch.

A. Method blanks. A method blank is included in every 10 samples, with a minimum of three blanks per preparation batch. These method blanks are used to evaluate gross contamination and to correct for background levels of $\mathrm{Hg}$ due to the reagents used during the oxidation and analytical steps. Values obtained from these blanks are used to calculate a BDL for the preparation batch. The DQO for $\mathrm{BDL}$ is $0.059 \mathrm{ng}$. 


$$
\mathrm{BDL}=3 * \sigma,
$$

where

$\mathrm{BDL}=$ Batch detection limit

$\sigma=$ Standard deviation of the method blanks for the preparation batch, in ng

B. Certified Reference Material. A CRM is included with every 10 samples. The CRMs are used to evaluate the efficiency of the oxidation and the accuracy of the analytical run. DQOs for CRMs are 80 to 120 percent recovery.

\section{Method Performance}

To evaluate method performance, two artificial water samples were created by adding different CRMs, $0.20814 \mathrm{~g}$ IAEA-405 polluted marine sediment and $0.0502 \mathrm{~g}$ MESS-2 marine sediment, to $2.0 \mathrm{~L}$ reagent water. IAEA-405 (certified concentration of $810 \mathrm{ng} / \mathrm{g}$ ) represents environmental samples at higher concentrations, and MESS-2 (certified concentration of $92 \mathrm{ng} / \mathrm{g}$ ) represents environmental samples at lower concentrations. Each of these artificial waters was filtered onto baked QFF filters to mimic environmental sample processing. Aliquots of the unfiltered samples were collected and analyzed to determine the beginning concentration of the solutions. Filtrate was also collected during sample processing and analyzed to determine how much mercury from the CRM dissolved in the reagent water.

Precision was evaluated by examining the percent relative standard deviation of the concentrations obtained from all analyses of the particulate filters for each concentration range. The percent relative standard deviation for the MESS-2 was 11.9 and for the IAEA-405 was 5.6 (tables 5 and 6). Percent relative standard deviations were calculated using the formula:

\section{PERCENT RELATIVE STANDARD DEVIATION}

$$
\% \operatorname{RSD}=\left(\mathrm{C}_{\mathrm{STDEV}} / \mathrm{C}_{\mathrm{AVE}}\right) * 100,
$$

where

$$
\begin{aligned}
& \% \mathrm{RSD}=\text { percent relative standard deviation } \\
& \mathrm{C}_{\mathrm{STDEV}}=\text { standard deviation of all samples } \\
& \mathrm{C}_{\mathrm{AVE}}=\text { average concentration of all samples }
\end{aligned}
$$

Accuracy was evaluated by calculating the theoretical and actual percent recovery of the CRM from each filter. The actual percent recovery utilized the analytically determined concentration for the unfiltered slurry, and the theoretical percent recovery used the mathematically derived concentration for the slurry based on the mass of the CRM added, the volume of water the CRM was added to, and the certified value for the CRM. Actual percent recoveries were calculated using the formula:

\section{ACTUAL PERCENT RECOVERY}

$$
\mathrm{R}=\left(\mathrm{C}_{\mathrm{P}} /\left(\mathrm{C}_{\mathrm{Ua}}-\mathrm{C}_{\mathrm{F}}\right)\right) * 100
$$

where

$\mathrm{R}=$ percent recovery

$\mathrm{C}_{\mathrm{P}}=$ analytically determined concentration of particulate sample

$\mathrm{C}_{\mathrm{Ua}}=$ analytically determined concentration of unfiltered slurry

$\mathrm{C}_{\mathrm{F}}=$ analytically determined concentration of filtrate

Theoretical percent recoveries were calculated using the formula:

\section{THEORETICAL PERCENT RECOVERY}

$$
\mathrm{R}=\left(\mathrm{C}_{\mathrm{P}} /\left(\mathrm{C}_{\mathrm{Ut}}-\mathrm{C}_{\mathrm{F}}\right)\right) * 100,
$$

where

$\mathrm{R}=$ percent recovery

$\mathrm{C}_{\mathrm{P}}=$ analytically determined concentration of particulate sample

$\mathrm{C}_{\mathrm{Ut}}=$ theoretical concentration of unfiltered slurry

$\mathrm{C}_{\mathrm{F}}=$ analytically determined concentration of filtrate

Table 5. Results for the analysis of MESS-2 CRM solution

\begin{tabular}{lccc}
\hline & $\begin{array}{c}\text { Particulate } \\
\mathbf{H g} \\
\text { (ng/L) }\end{array}$ & $\begin{array}{c}\text { Actual } \\
\text { Percent } \\
\text { Recovery }\end{array}$ & $\begin{array}{c}\text { Theoretical } \\
\text { Percent } \\
\text { Recovery }\end{array}$ \\
\hline 2.01 & 149 & 114 \\
2.08 & 155 & 118 \\
& 1.77 & 132 & 101 \\
& 1.84 & 137 & 105 \\
& 1.64 & 122 & 93 \\
& 1.52 & 113 & 87 \\
& 1.41 & 104 & 80 \\
& 1.69 & 126 & 96 \\
& 1.76 & 131 & 100 \\
\hline Average & 1.87 & 139 & 106 \\
Standard deviation & $\mathbf{1 . 7 6}$ & $\mathbf{1 3 1}$ & $\mathbf{1 0 0}$ \\
Percent relative & $\mathbf{0 . 2 1}$ & $\mathbf{1 5}$ & $\mathbf{1 2}$ \\
standard deviation & $\mathbf{1 1 . 9}$ & & \\
\hline & & &
\end{tabular}


Table 6. Results for the analysis of IAEA-405 CRM solution

\begin{tabular}{lccc}
\hline & $\begin{array}{c}\text { Particulate } \\
\mathbf{H g} \\
\text { (ng/L) }\end{array}$ & $\begin{array}{c}\text { Actual } \\
\text { Percent } \\
\text { Recovery }\end{array}$ & $\begin{array}{c}\text { Theoretical } \\
\text { Percent } \\
\text { Recovery }\end{array}$ \\
\hline & 76.3 & 103 & 95 \\
& 71.6 & 96 & 89 \\
& 70.3 & 94 & 87 \\
& 79.2 & 106 & 98 \\
& 75.4 & 101 & 93 \\
& 80.8 & 109 & 100 \\
& 82.9 & 111 & 103 \\
\hline Average & 80.0 & 108 & 99 \\
Standard deviation & 80.3 & 108 & 99 \\
Percent relative & $\mathbf{7 7 . 4}$ & $\mathbf{1 0 4}$ & $\mathbf{9 6}$ \\
$\quad$ standard deviation & $\mathbf{4 . 3}$ & $\mathbf{6}$ & $\mathbf{5}$ \\
\hline
\end{tabular}

For the MESS-2 solution, the analytically determined concentration of the unfiltered slurry was $1.89 \mathrm{ng} / \mathrm{L}$, the theoretical concentration of the unfiltered slurry was $2.30 \mathrm{ng} / \mathrm{L}$, and the analytically determined filtrate concentration was $0.54 \mathrm{ng} / \mathrm{L}$. Actual recoveries ranged from 104 to 155 percent, with an average of 131 and a standard deviation of 15 (table 5). The theoretical recoveries ranged from 80 to 118 percent, with an average of 101 and a standard deviation of 11. For the IAEA-405 solution, the analytically determined concentration of the unfiltered slurry was $78.0 \mathrm{ng} / \mathrm{L}$, the theoretical concentration of the unfiltered slurry was $84.3 \mathrm{ng} / \mathrm{L}$ and the analytically determined concentration of the filtrate was $3.58 \mathrm{ng} / \mathrm{L}$. Actual recoveries ranged from 94 to 111 percent, with an average of 104 and a standard deviation of 6 (table 6). Theoretical recoveries ranged from 87 to 103 percent, with an average of 96 and a standard deviation of 5 .

\section{Summary}

This document describes the methods used by the Wisconsin District Mercury Lab to analyze solids and suspended solids for total mercury concentration. Because the procedures used to process and analyze solids and suspended solids differ, two distinct analytical performance studies were conducted and the results are presented.

The method detection limit established for the solids procedure as outlined in this report is $0.3 \mathrm{ng}$ total mercury in a digestion bomb, which was acceptable because it is substantially below the levels commonly encountered in natural samples from a wide range of environments. The mass of sample digested varies, which gives a minimum sample reporting limit ranging from $0.6 \mathrm{ng} / \mathrm{g}$ to $6 \mathrm{ng} / \mathrm{g}$. The method precision, calculated as the percent relative standard deviation, ranged from 10.0 to 12.8 percent. The accuracy of the procedure, which was determined from recovery tests for spiked samples, ranged from 85 to 113 percent and was acceptable.

The second method documented in this report is for sample preparation and analysis of suspended solids on baked quartz fiber filter. Two artificial raw water samples were created by suspending two different certified reference materials (IAEA-405 and MESS-2) in reagent water and filtering them to create suspended solids samples. The method detection limit was established by analyses of multiple filters of the MESS-2, and a limit of $0.059 \mathrm{ng}$ was achieved. Based on the range of water filtered, the minimum sample reporting limit varies from $0.059 \mathrm{ng} / \mathrm{L}$ to $1.18 \mathrm{ng} / \mathrm{L}$. Precision was evaluated by calculating percent relative standard deviation from analyses of replicate filters. Percent relative standard deviations were 5.6 and 11.9 for the IAEA-405 and MESS-2 certified reference materials, respectively. Accuracy was evaluated from percent recovery of total mercury on the filters from their target value. Target values were determined by subtracting the analytically determined concentration of the filtrate from the theoretical raw water sample concentration as well as the analytically determined raw water sample concentrations. Recoveries ranged from 94 to 155 percent, with an overall mean and standard deviation of 118 percent and 18 , respectively, for the analytically determined concentrations. For the theoretical concentrations, the recoveries ranged from 80 to 118 percent, with an overall mean of 99 percent and a standard deviation of 9 . 


\section{References}

Biester, H., Gosar, M., and Covelli, S., 2000, Mercury speciation in sediment affected by dumped mining residues in the drainage area of the Idrija Mercury Mine, Slovenia: Environmental Science and Technology, v. 34, p. 3330-3336.

DeWild, J.F, Olson, M.L., and Olund, S.D., 2002, Determination of Methyl Mercury by Aqueous Phase Ethylation, Followed by Gas Chromatographic Separation with Cold Vapor Atomic Fluorescence Detection: U.S. Geological Survey Open-File Report 01-445, 14 p.

DeWild, J.F., Olund, S.D., Olson, M.L., and Tate, M.T., 2004, Methods for the Preparation and Analysis of Solids and Suspended Solids for Methylmercury: U.S. Geological Survey Techniques and Methods book 5, chap. A7, 13 p.

Gustin, M.S., Lindberg, S.E., Austin, K., Coolbaugh, M., Vette, A., and Zhang, H., 2000, Assessing the contribution of natural sources to regional atmospheric mercury budgets: The Science of the Total Environment, v. 259, p. 61-72.

Krabbenhoft, D.P., Wiener, J.G., Brumbaugh, W.G., Olson, M.L. DeWild, J.F., and Sabin T.J., 1999, A national pilot study of mercury contamination of aquatic ecosystems along multiple gradients, in Morganwalp, D.W., and Buxton, H.T., eds., U.S. Geological Survey Toxic Substances Hydrology Program-Proceedings of the technical meeting, Charleston, S.C., March 8-12, 1999-Volume 2 of 3-Contamination of hydrologic systems and related ecosystems: U.S. Geological Survey Water-Resources Investigations Report 99-4018-B, p. 147-160.

Mason, R.P., Fitzgerald, W.F., and Morel, F.M.M., 1994, The aquatic biogeochemical cycling of elemental mercury-Anthropogenic influences: Geochimica et Cosmochimica Acta, v. 58, p. 3191-3198.

Nater, E.A., and Grigal, D.F., 1992, Regional trends in mercury distribution across the Great Lakes states, north central USA: Nature, v. 358, p. 139-141.

Olson, M.L., and DeWild, J.F., 1999, Low-level techniques for the collection and species-specific analysis of low levels of mercury in water, sediment, and biota, in Morganwalp, D.W., and Buxton, H.T., eds., U.S. Geological Survey Toxic Substances Hydrology Program-Proceedings of the Technical Meeting, Charleston, South Carolina, March 8-12, 1999-Volume 2 of 3-Contamination of Hydrologic Systems and Related Ecosystems: U.S. Geological Survey Water-Resources Investigations Report 99-4018-B, p. 191-200.
U.S. Environmental Protection Agency, 1990, Guidelines establishing test procedures for the analysis of pollutants (Appendix B, Part 136, Definition of procedures for the determination of the method detection limit-Revision 1.11): Revised as of July, 1999, p. 537-539.

U.S. Environmental Protection Agency, 2002, Method 1631, Revision E: Mercury in water by oxidation, purge and trap, and cold vapor atomic fluorescence spectrometry: EPA-821-R-02-019, Office of Water, Washington D.C., 36 p.

Wiener, J.G., Krabbenhoft, D.P., Heinz, G.H., and Scheuhammer, A.M., 2003, Ecotoxicology of mercury, chapter 16 in Hoffman, D.J., Rattner, B.A., Burton, Jr., G.A., and Cairns, Jr., J., eds., Handbook of Ecotoxicology, (2d ed.): Boca Raton, Fla., CRC Press, p. 407-461. 
83 Printed on recycled paper 